\title{
Molecular Basis of Ribotype Variation in the Seventh Pandemic Clone and its 0139 Variant of Vibrio cholerae
}

\author{
Ruiting Lan, Peter R Reeves/ ${ }^{+}$
}

Department of Microbiology, University of Sydney, NSW 2006, Sidney, Australia

Ribotyping has been widely used to characterise the seventh pandemic clone including South American and O139 variants which appeared in 1991 and 1992 respectively. To reveal the molecular basis of ribotype variation we analysed the rrn operons and their flanking regions. All but one variation detected by $\mathrm{BglI}$, the most discriminatory enzyme, was found to be due to changes within the rrn operons, resulting from recombination between operons. The recombinants are detected because of the presence of a $\mathrm{BglI}$ site in the 16S gene in three of the nine rrn operons and/or changes of intergenic spacer types of which four variants were identified. As the frequency of $\mathrm{rrn}$ recombination is high, ribotyping becomes a less useful tool for evolutionary studies and long term monitoring of the pathogenic clones of Vibrio cholerae as variation could undergo precise reversion by the same recombination event.

Key words: ribotyping - rrn recombination - seventh pandemic - O139 - Vibrio cholerae

Vibrio cholerae is the agent responsible for cholera which was first described in 1854 . However, the natural habitat of $V$. cholerae is the aquatic environment. Environmental V. cholerae are diverse and most are nontoxigenic. There are more than $190 \mathrm{O}$ antigens identified (Yamai et al. 1997). The best known forms are $\mathrm{O} 1$ and recently $\mathrm{O} 139$. Both cause cholera, currently mostly in developing countries. Seven pandemics of cholera are recognised since 1817. The seventh started in 1961 and continues to the present day.

The seventh pandemic clone has been studied by various molecular methods. Ribotyping, a form of restriction fragment length polymorphism analysis using rRNA genes, was shown to be very discriminatory in revealing variation. rRNA sequences are highly conserved and the genes ( $r r n)$ are present as multiple copies in the genome of many bacteria. The typing therefore provides information on several flanking regions simultaneously. There have been quite a few studies on the epidemiology and molecular typing of $V$. cholerae. Koblavi et al. (1990) were the first to employ ribotyping to fingerprint $V$. cholerae strains and Popovic et al. (1993) proposed a standardised scheme for typing $V$. cholera using BgII restriction enzyme to allow public laboratories to follow the movement and

\footnotetext{
This work was supported by a grant from the National Health and Medical Research Council of Australia. ${ }^{+}$Corresponding author. Fax: +612 9351.4571. E-mail: reeves@angis.usyd.edu.au

Received 15 June 1998

Accepted 30 July 1998
}

identify the origins of $V$. cholerae strains. Ribotyping has since been widely used to characterise the sixth pandemic clone (Faruque et al. 1993) and the seventh pandemic clone (Karaolis et al. 1994, Faruque et al. 1995), the South American and O139 variants (Wachsmuth et al. 1993, Popovic et al. 1995, Dalsgaard et al. 1997) and other O1 outbreaks (Coelho et al. 1995) . Ribotype variation has been found in the South American isolates in the four years of its spread from 1991 (Dalsgaard et al. 1997) and in the O139 variant which appeared in 1992 (Popovic et al. 1995, Faruque et al. 1997).

As the $r r n$ operons are conserved, variation detected in ribotyping has been generally assumed to be due to variation in flanking regions. We studied the changes behind ribotype variation to help us understand the evolution of pandemic clones (Lan \& Reeves 1998).

\section{RIBOTYPE VARIATION IN THE SEVENTH PANDEMIC CLONE}

The seventh pandemic clone is an very interesting clone to study because accurate dates of development are known. In our ribotyping study with a total of 47 strains isolated from 1961 (Indonesia and Hong Kong) to 1993 including African and Asian isolates (Karaolis et al. 1994). BglI detects most of the polymorphisms. The $B g l \mathrm{I}$ ribotypes are summarised in Table I. There are 11 ribotypes. Ribotype $\mathrm{G}$ was present at the start of the pandemic and 14 type $G$ strains are all from Asia. In the first 10 years of spread there was no detectable variation. In fact after 1966 there was a lull period with relatively little cholera. Ribotype $\mathrm{H}$ appeared in 1970 in Asia and spread to Africa; 
Africa being free from cholera before 1970. The resurgence in 1970 seems to be associated with a substantial increase in genetic variation. There are other minor ribotypes with one or two isolates from Asia and Africa.

TABLE I

Summary of $B g l \mathrm{I}$ ribotypes detected in the seventh pandemic clone (Karaolis et al. 1994)

\begin{tabular}{lcll}
\hline Ribotype & $\begin{array}{l}\text { No. } \\
\text { isolates }\end{array}$ & $\begin{array}{l}\text { Year of } \\
\text { isolation }\end{array}$ & $\begin{array}{l}\text { Location } \\
\text { of isolation }\end{array}$ \\
\hline $\mathrm{G}$ & 14 & $1961-1991$ & Asian region only \\
$\mathrm{H}$ & 22 & $1970-1993$ & Asia and Africa \\
$\mathrm{I}$ & 1 & 1971 & Burma \\
$\mathrm{J}$ & 2 & 1971,1974 & Chad \\
$\mathrm{K}$ & 1 & 1972 & Senegal \\
$\mathrm{L}$ & 1 & 1978 & Malaysia \\
$\mathrm{M}$ & 1 & 1988 & Zaire \\
$\mathrm{N}$ & 2 & 1989,1992 & HK \& Indonesia \\
$\mathrm{O}$ & 1 & 1990 & Malawi \\
$\mathrm{P}$ & 1 & 1991 & India \\
$\mathrm{Q}$ & 1 & 1993 & Indonesia \\
\hline
\end{tabular}

\section{rrn OPERON FEATURES IN THE EARLY SEVENTH PANDEMIC ISOLATE M803}

Majumder et al. (1996) mapped seven operons to the genome of $V$. cholerae strain 569B. However, ribotyping in $V$. cholerae detects 10 or more bands in BglI digests in the seventh pandemic isolates (Karaolis et al. 1994) and it was not clear how to assemble seven operons from the patterns. We know that in general a $r r n$ operon has three genes in the order $16 \mathrm{~S}-23 \mathrm{~S}-5 \mathrm{~S}$ and there is a unique I-Ceu I site in the 23S gene (Liu \& Sanderson 1995). We used 2 DNA probes, one specific to the 5 ' region of the $16 \mathrm{~S}$ gene and the other specific to the $3^{\prime}$ region of the $23 \mathrm{~S}$ gene, and an oligo probe from $16 \mathrm{~S} 5$ ' end to probe Southern blots of $B g l \mathrm{I}$ digests. From the probings we concluded that there are nine operons in the strain of M803, an early seventh pandemic isolate. Three operons have a $B g l \mathrm{I}$ in their $16 \mathrm{~S}$ gene. We also used the $23 \mathrm{~S}$ probe to probe strain M803 DNA digested with I-Ceu I and $B g l \mathrm{I}$, which showed only a strong $1 \mathrm{~kb}$ band rather nine bands as expected and thereby discovered that there is a $B g l \mathrm{I}$ site near the end of the $23 \mathrm{~S}$ gene. However, the number of operons is different from the seven operons detected by Majumder et al. (1996). Later we discovered that two of the nine operons are in tandem with another operon. Thus there are only seven loci on the chromosome. A recent study using pulsed-field gel electrophoresis of I-ceu I digest from the Majumder group (Nandi et al. 1997) found that there are nine fragments, one of which is $6 \mathrm{~kb}$, the equivalent of a tandem operon. However, we could not reconcile our data with their conclusion of eight independent $r r n$ loci.

\section{IDENTIFICATION OF ALTERNATIVE FRAGMENTS FOR EACH RIBOTYPE CHANGES BY OPERON SPE- CIFIC PROBING}

Due to the presence of a $B g l \mathrm{I}$ site at the end of the 23S genes, changes in the 23S proximal DNA are not detected by ribotyping and all $B g l \mathrm{I}$ variation involves the $16 \mathrm{~S}$ genes or their flanking regions. PCR walking was used to obtain sequence immediately upstream of the $16 \mathrm{~S}$ genes. We then made operon specific probes and probed $B g l \mathrm{I}$ digests of different ribotypes to analyse the variation. The probing experiments are summarised in the Fig. with schematic representation of each $B g l \mathrm{I}$ change.

For operons $\mathrm{B}, \mathrm{C}$, and $\mathrm{G}$, alternative bands were identified through probing. For operon B, the alternative bands are $7.2 \mathrm{~kb}, 12.3 \mathrm{~kb}$ and $19.1 \mathrm{~kb}$. We found that these alternative bands result from loss of the $B g l \mathrm{I}$ site in the $16 \mathrm{~S}$ gene.The $7.2 \mathrm{~kb}$ band has only 5 ' end of the $16 \mathrm{~S}$ gene because of the $B g l \mathrm{I}$ site in the $16 \mathrm{~S}$ gene. We sequenced the region around the $B g I \mathrm{I}$ site in $\mathrm{M} 803$, M811, and M662 of operon B. A single base difference from $\mathrm{C}$ to $\mathrm{T}$ at base 849 determines the presence or absence of the elevenmer $B g l$ I recognition sequence. However the change to $19.1 \mathrm{~kb}$ in M662 from 7.2 $\mathrm{kb}$ in M803 or $12.3 \mathrm{~kb}$ in M811 also involves

\begin{tabular}{|c|c|c|c|c|c|}
\hline Type strain & $\frac{\mathscr{c}}{\tilde{\Sigma}}$ & $\stackrel{\vec{d}}{\stackrel{\infty}{z}^{2}}$ & 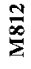 & $\stackrel{\text { 엉 }}{\stackrel{\infty}{\Sigma}}$ & $\frac{G}{8}$ \\
\hline Ribotype & G & I & $\mathbf{J}$ & $\mathrm{M}$ & $Q$ \\
\hline
\end{tabular}

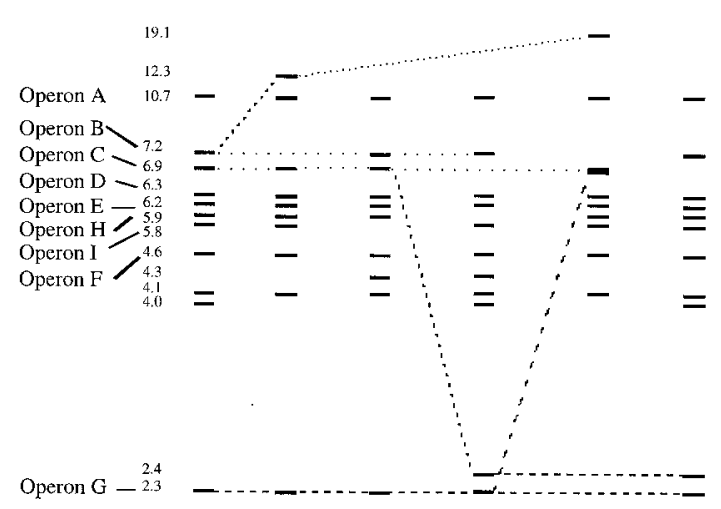

Schematic representation of BglI ribotype data of Vibrio cholerae seventh pandemic isolates to indicate variation in specific operons among ribotypes $\mathrm{G}, \mathrm{I}, \mathrm{J}, \mathrm{M}$ and $\mathrm{Q}$ and the $\mathrm{O} 139$ variant $\mathrm{R}$. The operons are indicated to the left for each band representing the 5' $16 \mathrm{~S}$ gene. Alternative bands of the same operon are indicated by a dotted line for operons B, C, and G. The size of each band is indicated on the left. After Karaolis et al. (1994) and Lan and Reeves (1998). 
change in the flanking region of the operon. We have yet to walk to that $B g l$ site. For operon C operon-specifc probing showed that the $2.4 \mathrm{~kb}$ band in M825 is a replacement of the $6.9 \mathrm{~kb}$ fragment which is due to the creation of a $B g l$ I site in the $16 \mathrm{~S}$ gene. For operon $\mathrm{G}$ the alternative band for the $2.3 \mathrm{~kb}$ band is similar in size to the $6.9 \mathrm{~kb}$ operon $\mathrm{C}$ fragment. Apparently this resulted in the newly created band being masked. This change is due to the loss of $B g l \mathrm{I}$ site in the $16 \mathrm{~S}$ gene.

We found that operons $\mathrm{H}$ and I are tandem operons and absence of a band means deletion of the operon. We did Southern probing of I-ceu I digests to show that $\mathrm{H}$ and $\mathrm{I}$ are immediately downstream of other $r r n$ operons. For tandem operons I- $\mathrm{Ceu}$ I digestion, which cuts uniquely in $23 \mathrm{~S}$ gene, would release a fragment from the I-Ceu I site of the upstream operon to the I-Ceu I site of the downstream operon.

\section{SIZE VARIATION IN INTERGENIC SPACERS}

The bands of 4.0, 4.1 and $4.3 \mathrm{~kb}$ in the Fig. are fragments having part of $16 \mathrm{~S}$ gene and the whole of $23 \mathrm{~S}$ gene and variation in size of these bands is due to size differences of the intergenic spacer. We analysed the intergenic spacer of the three operons $\mathrm{B}, \mathrm{C}$ and $\mathrm{G}$. The spacer region was amplified by nested PCR. Three types of spacers were initially found: small (S) $411 \mathrm{bp}$, large (L) $692 \mathrm{bp}$, and medium (M1) 488 bp. We later identified another spacer variant (M2) $587 \mathrm{bp}$.

\section{REASSORTMENT OF SPACER TYPES AND $r r n$ RE- COMBINATION}

The nature of variation detected by $B g l \mathrm{I}$ ribotyping is summarised in Table II, including eleven ribotypes of the seventh pandemic and its O139 variant. It is evident that there was extensive reassortment of spacers. For operon B, there are four forms: S, $B g l \mathrm{I}-; \mathrm{L}, B g l \mathrm{I}+; \mathrm{L}, B g l \mathrm{I}-;$ and M2, $B g l \mathrm{I}$ - generated from the $\mathrm{S}, B g l \mathrm{I}+$ form of the early strains. Both operons $\mathrm{C}$ and $\mathrm{G}$ have two additional forms. So there are in total eight types of changes to $r r n$ operons which we attribute to homologous recombination between operons. We don't know why the most frequent changes are in operon B. The other frequent change is deletion of operon I. Deletions might be due to single or multiple events. The majority of the ribotypes seems to have arisen from ribotype $\mathrm{G}$ by a single recombination event though $\mathrm{M}, \mathrm{N}$ and $\mathrm{Q}$ require two or more recombinational changes.

\section{RIBOTYPE VARIATION IN THE O139 VARIANT}

It is well recognised from multilocus enzyme electrophoresis (MLEE) and other data that the O139 Bengal strain is derived from the seventh pandemic strain. A single ribotype, $R$, (represented by strain M831) was identified in our previous study (Karaolis et al. 1994). The O139 clone is very similar to the Asia-dominant ribotype G. The only difference in the $B g l$ Iigests of ribotypes R and $\mathrm{G}$ is that in ribotype $\mathrm{R}$ the $6.9 \mathrm{~kb}$ operon $\mathrm{C}$ fragment

\section{TABLE II}

Spacer types and status of $B g l \mathrm{I}$ site in the 16S RNA gene for operons B, C and G and status of operons $\mathrm{H}$ and I in the ribotypes (G-Q) of the seventh pandemic clone and ribotype $\mathrm{R}$ of the $\mathrm{O} 139$ variant

\begin{tabular}{|c|c|c|c|c|c|c|c|c|c|}
\hline \multirow[b]{2}{*}{ Ribotype } & \multirow[b]{2}{*}{ Strain } & \multicolumn{2}{|c|}{ Operon B } & \multicolumn{2}{|c|}{ Operon $\mathrm{C}$} & \multicolumn{2}{|c|}{ Operon G } & \multirow{2}{*}{$\begin{array}{l}\text { Operon } \\
\mathrm{H}\end{array}$} & \multirow{2}{*}{$\begin{array}{c}\text { Operon } \\
\text { I }\end{array}$} \\
\hline & & Spacer $^{a}$ & $B g l$ site ${ }^{b}$ & Spacer & $B g l I$ site & Spacer & $B g l I$ site & & \\
\hline $\bar{G}$ & M803 & $\mathrm{S}$ & + & M1 & - & M1 & + & Present & \\
\hline \multicolumn{10}{|l|}{ Present } \\
\hline $\mathrm{H}$ & M807 &.$^{c}$ & . & . & . & . & . & . & Del \\
\hline I & M811 & $\mathrm{L}$ & - & . & . & . & . & . & . \\
\hline $\mathrm{J}$ & M812 & $\mathrm{L}$ & . & . & . & . & . & . & Del \\
\hline $\mathrm{K}$ & M813 & . & . & $\mathrm{S}$ & + & . & . & . & del \\
\hline $\mathrm{L}$ & M820 & $\mathrm{L}$ & - & . & . & . & . & . & Del \\
\hline M & M825 & $\mathrm{L}$ & . & . & + & $\mathrm{S}$ & . & $\mathrm{Del}^{d}$ & . \\
\hline $\mathrm{N}$ & M799 & M2 & - & . & . & . & - & . & . \\
\hline $\mathrm{O}$ & M826 & $\mathrm{L}$ & . & . & . & . & . & Del & Del \\
\hline $\mathrm{P}$ & M654 & . & - & . & . & . & . & . & Del \\
\hline Q & M662 & M2 & - & . & . & . & - & . & . \\
\hline $\mathrm{R}$ & M831 & . & . & . & + & . & . & . & Del \\
\hline
\end{tabular}

$a$ : the spacer types are small (S) 431bp, large (L) 711bp, medium (M1) 509bp and a variant of size between M1 and L (M2) 607bp; $b:+/$ - indicates presence or absence of $B g l$ I site at base 838 of the $16 \mathrm{~S}$ RNA gene; $c$ : status identical to ribotype $\mathrm{G}$ is indicated by a dot; $d$ : deletion of an operon. 
is replaced by a $2.4 \mathrm{~kb}$ band due to the gain of a $B g l$ I site in the $16 \mathrm{~S}$ gene. It is very interesting that Popovic et al (1995) detected two ribotypes, 3a and $5 \mathrm{a}$, in $\mathrm{O} 139$ isolates. Ribotype $3 \mathrm{a}$ is identical to ribotype R. Ribotype 5a differs from ribotype 3 a by the absence of operon I. Popovic et al (1995) noted that ribotypes $3 \mathrm{a}$ and $5 \mathrm{a}$ are very similar to their ribotypes 3 and 5 of seventh pandemic clone respectively, which implied that ribotype 3a may be derived from ribotype 3 and 5 a derived from 5 . Most likely ribotype 5a is derived from ribotype 3 a through an independent operon I deletion rather than from ribotype 5. If $3 \mathrm{a}$ and $5 \mathrm{a}$ were derived separately, it would require independent transfer of a new $\mathrm{O}$ antigen gene cluster. This also illustrates the weakness of ribotyping for defining relationships between strains.

\section{RIBOTYPE VARIATION IN THE SOUTH AMERICAN VARIANT}

In our ribotyping study (Karaolis et al. 1994), only one South American isolate was included which belongs to ribotype H. Dalsgaard et al. (1997) analysed 50 South American isolates isolated in Peru from 1991 to 1995 and found four ribotypes: R1, R2, R3 and R4. The publication of good quality Southern blot by Dalsgaard et al. (1997) and use of probes identical to our study allow us to interpret their results in terms of the basis of ribotype changes. $\mathrm{R} 1$ is identical to our ribotype $\mathrm{H}$. R2 differs from $\mathrm{R} 1$ by the appearance of a $4.3 \mathrm{~kb}$ band and disappearance of a $4.0 \mathrm{~kb}$ band representing the change in spacer type from small to large in operon $\mathrm{C}$ by $r r n$ recombination. $\mathrm{R} 3$ differs from $\mathrm{R} 1$ in the presence of a 5.6kb band which is equivalent to the position of operon I and the pattern is identical to our ribotype $\mathrm{G}$, the frequent ribotype isolated in Asian region only. It seems that a R1 (ribotype $\mathrm{H}$ pattern) strain reversed back to ribotype $G$ pattern by recreation of the tandem operon I, presumably also due to $r r n$ recombination. This is an good example where identical ribotypes may not mean genetic similarity. It is possible that the $\mathrm{R} 3$ strain is actually a ribotype G strain separately introduced into South America and R3 is not derived from R1. The early South American isolates differ at the locus of leucine aminopeptidase in MLEE from other seventh pandemic isolates. Therefore the allele profile could be used to determine whether $\mathrm{R} 3$ is derived from $\mathrm{R} 1$. $\mathrm{R} 4$ is very different from the other three ribotypes. In our opinion R4 is not developed from R1.

\section{GENERAL CONCLUSIONS}

It has always been assumed that ribotype variation is due to changes outside the rrn operons. This study shows that ribotyping detects two types of changes of very different nature: within operon changes produced by rrn recombination or mutational changes outside the operons. For the seventh pandemic clone the varaition observed is predominantly $r r n$ recombination. The frequency of $r r n$ recombination is high. Ten new ribotypes were found in 46 isolates over 33 year span in our previous study (Karaolis et al. 1994). Nine of the ten ribotypes were generated by $r r n$ recombination. There are new ribotypes found in the South American isolates in its first four years spread (Dalsgaard et al. 1997). Similarly new ribotypes were found in the O139 variant (Popovic et al. 1995, Faruque et al. 1997).Therefore, the level of parallel and reversal changes will also be high. And similar ribotype does not necessarily reflect genetic similarity. Thus ribotyping is not suitable for long term monitoring of the seventh pandemic clone or any $V$. cholerae clones. Other species need to be studied to see whether this is a general phenomenon.

However, some laboratories may wish to continue to use $B g l$ ribotyping for typing seventh pandemic isolates as an accessary tool as it has been well established technically. In such case we recommend using a fragment from the $16 \mathrm{~S}$ gene encompassing the $B g l \mathrm{I}$ site as a probe, eg the $1 \mathrm{~kb}$ fragment from base 21 to base 1097 of the 16 S gene in this study, which will produce bands of uniform intensity and identical patterns to probing using a mixture of $16 \mathrm{~S}$ and 23S rRNA or rDNA (Lan \& Reeves 1998). Using a 16S and 23S rRNA as probe the hybridisation signal for those fragments having only part of the $16 \mathrm{~S}$ gene is much weaker than for other fragments which may lead to misidentification of patterns. The use of probes including $5 \mathrm{~S}$ gene or any flanking sequences in addition to $16 \mathrm{~S}$ and $23 \mathrm{~S}$ genes is not recommended as it produces ribotyping patterns not comparable to those of other laboratories. Separation of the four bands between $6.3 \mathrm{~kb}$ to $5.8 \mathrm{~kb}$, and the three bands between $4.0 \mathrm{~kb}$ to 4.3 $\mathrm{kb}$ is usually poor. Reference ribotypes representing each band variation should be included for comparison to determine the present or absent of a band to increase accuracy.

\section{REFERENCES}

Coelho A, Andrade JRC, Vincente ACP, Salles CA. 1995. New variant of Vibrio cholerae $\mathrm{O} 1$ from clinical isolates in Amazonia. J Clin Microbiol 33: 114-118.

Dalsgaard A, Skov MN, Serichantalergs O, Echeverria P, Meza R, Taylor DN 1997. Molecular evolution of Vibrio cholerae O1 strains isolated in Lima, Peru, from 1991 to 1995. J Clin Microbiol 35: 1151-1156.

Faruque SM, Ahmed KM, Siddique AK, Zaman K, Alim ARMA, Albert MJ 1997. Molecular analysis of toxigenic Vibrio cholerae $\mathrm{O} 139$ bengal strains isolated in Bangladesh between 1993 and 1996: evidence for emergence of a new clone of the bengal Vibrios. $J$ Clin Microbiol 35: 2299-2306. 
Faruque SM, Alim ARMA, Rahman MM, Siddique AK, Sack RB, Albert MJ 1993. Clonal relationships among Classical Vibrio cholerae $\mathrm{O} 1$ strains isolated between 1961 and 1992 in Bangladesh. J Clin Microbiol 31: 2513-2516.

Faruque SM, Roy SK, Alim ARMA, Siddique AK, Albert MJ 1995. Molecular epidemiology of toxigenic Vibrio cholerae in Bangladesh studies by numerical analysis of rRNA gene restriction patterns. J Clin Microbiol 33: 2833-2838.

Karaolis DKR, Lan R, Reeves PR 1994. Molecular evolution of the 7th pandemic clone of Vibrio cholerae and its relationship to other pandemic and epidemic V. cholerae isolates. J Bacteriol 176: 6199-6206.

Koblavi S, Grimont F, Grimont PAD 1990. Clonal diversity of Vibrio cholerae O1 evidenced by rRNA gene restriction patterns. Res Microbiol 141: 645657.

Lan R, Reeves PR 1998. Recombination between rRNA operons created most of the ribotype variation observed in the seventh pandemic clone of Vibrio cholerae. Microbiology 144: 1213-1221.

Liu S-L, Sanderson KE 1995. Rearrangements in the genome of the bacterium Salmonella typhi. Proc Natl Acad Sci USA 92: 1018-1022.

Majumder R, Sengupta S, Khetawat G, Bhadra R, K, Roychoudhury S, Das J 1996. Physical map of the genome of Vibrio cholerae 569B and localization of genetic markers. J Bacteriol 178: 1105-1112.

Nandi S, Khetawat G, Sengupta S, Majumder R, Kar S, Bhadra RK, Roychoudhury S, Das J 1997. Rearrangements in the genome of Vibrio cholerae strains belonging to different serovars and biovars. Int J Syst Bacteriol 47: 858-862.

Popovic T, Bopp CA, Olsvik O, Wachsmuth K 1993. Epidemiologic application of a standardized ribotype scheme for $V$. cholerae O1. J Clin Microbiol 31: 2474-2482.

Popovic T, Fields PI, Olsvik O, Wells JG, Evins GM, Cameron DN, Farmer III JJ, Bopp CA, Wachsmuth K, Sack RB, Albert MJ, Nair GB, Shimada T, Feeley JC 1995. Molecular subtyping of toxigenic Vibrio cholerae $\mathrm{O} 139$ causing epidemic cholera in India and Bangladesh, 1992-1993. J Infect Dis 171: 122127.

Wachsmuth IK, Evins GM, Fields PI, Olsvik O, Popovic T, Bopp CA, Wells JG, Carrillo C, Blake PA 1993. The molecular epidemiology of cholera in Latin America. J Infect Dis 167: 621-626.

Yamai S, Okitsu T, Shimada T, Katsube Y 1997. Distribution of serogroups of Vibrio cholerae non-O1 nonO139 with specific reference to their ability to produce cholera toxin, and addition of novel serogroups. J Japan Assoc Infect Dis 71: 1037-1045. 
